\title{
Rancang Bangun Sistem Informasi Pengelolaan Kendaraan di PT PLN (Persero) Area Mojokerto
}

\author{
Mukhamad Masrur ${ }^{1}$, Novan Adi Mustofa ${ }^{2}$, Misfah Sofanni ${ }^{3}$ \\ ${ }^{1,2,3}$ Sistem Informasi, Fakultas Teknik, Universitas Pesantren Tinggi Darul 'Ulum (Unipdu), Jombang \\ E-mail: ${ }^{1}$ mukhamadmasrur@ft.unipdu.ac.id
}

\begin{abstract}
Abstrak
PT Perusahaan Listrik Negara (PT PLN) (Persero) Area Mojokerto merupakan salah satu cabang dari PT PLN (Persero) Distribusi Jawa Timur yang bergerak di bidang pelayanan terhadap pelanggan. Pada PT PLN (Persero) Area Mojokerto terdapat sebuah bagian yang khusus menangani pengelolaan kendaraan. Proses pengelolaan kendaraan pada PT PLN (Persero) Area Mojokerto saat ini masih menggunakan Microsoft Excel, sehingga belum bisa memberikan pelayanan cepat dalam proses peminjaman mobil dan kurang efisien dalam perihal penyimpanan data. Permasalahan yang akan dituntut ada penyelesaiannya agar pegawai mendapat pelayanan secara proporsional akan pelayanan yang tersedia. Solusi dari permasalahan tersebut adalah membuat adanya aplikasi baru. Adapun aplikasi yang dibuat yaitu Aplikasi berbasis Web dengan menggunakan bahasa pemrograman PHP dan database MySQL. Hasil penelitian ini berupa sebuah Aplikasi Pengelolaan Kendaraan. Dengan adanya solusi yang demikian mampu meningkatkan terlaksana proses kerja pada bagian manajemen kendaraan yang lebih maksimal serta mempermudah pelayanan pada proses peminjaman kendaraan.

Kata kunci: PT PLN, pengelolaan kendaraan, sistem informasi berbasis web.
\end{abstract}

\begin{abstract}
PT Perusahaan Listrik Negara (PT PLN) (Persero) Area Mojokerto is one of PT PLN (Persero) branch for East Java Distribution, which is engaged in the customer service. Where in PT PLN (Persero) Area Mojokerto there is a special section dealing with the management of the vehicle. At PT PLN (Persero) Area Mojokerto current system is the process of managing the vehicle is still using Microsoft Excel, so can not provide fast service in the process of borrowing the car and less efficient in the subject of data storage. Issues to be prosecuted for there is no solution so that employees would receive proportionately service available services. The solution to these problems is to make the new application. The application is made that Web-based applications using the programming language PHP and MySQL database. The results of this study are a Vehicle Management Application. With the solution that is thus able to improve work processes executed on the vehicle management more leverage and facilitate services in the process of borrowing the vehicle.
\end{abstract}

Key word: PT PLN, vehicle management, web-based information system.

\section{Pendahuluan}

Perkembangan teknologi informasi di Indonesia yang semakin pesat dan penyabaran berbagai macam informasi yang semakin luas dengan media internet. Seiring dengan berjalannya waktu, sebuah perusahaan akan melakukan perbaikan-perbaikan untuk membuat perusahaan tersebut lebih maju dan berkembang. Dengan adanya suatu sistem informasi dapat membantu dalam pengembangan mutu maupun kinerja dari sebuah perusahaan (Subchan \& Ardi, 2014). Karena sistem informasi digunakan untuk menampilakan informasi dengan cepat tanpa adanya redudansi yang tidak diperlukan. Juga dengan adanya sistem informasi dapat menghindari kesalahan-kesalahan yang disebabkan oleh user atau pegawai, staf dan manajer. Selain daripada cepat dan mudah dalam menampilkan informasi yang baru oleh adanya update data yang dilakukan admin, sistem informasi juga memberikan keringanan dalam menghemat suatu biaya pengalokasian ruang dimana biasanya digunakan sebagai tempat pengarsipan dari sistem manual. Hal tersebut terjadi dikarenakan oleh adanya database berupa kumpulan data yang telah diolah dan disimpan dalam komputer (Lubis, 2013).

PT Pembangkit Listrik Negara (PT PLN) (Persero) Area Mojokerto merupakan perusahaan listrik negara yang bergerak di bidang pelayanan terhadap pelanggan. Pada PT PLN (Persero) Area Mojokerto terdapat sebuah bagian khusus yang bertugas mengelola kendaraan dinas. Dalam penyimpanan dan pengolahan data masih menggunakan Microsoft Office Excel sehingga belum terdokumentasi dengan

24 | Register: Jurnal Ilmiah Teknologi Sistem Informasi, Januari 2015, Volume 1, Nomor 1 
baik dan menyulitkan pada saat dibutuhkan. Pada proses pengajuan peminjaman kendaraan dinas, pemohon masih harus mengisi formulir permohonan pada kertas yang telah disediakan. Setelah pengisian selesai formulir permohonan tersebut diserahkan kepada kepala bagian kendaraan untuk proses validasi permohonan. Kemudian formulir-formulir tersebut disimpan dalam lemari yang digunakan sebagai tempat penyimpanan data-data atau sering disebut sebagai tempat pengarsipan yang sewaktu-waktu akan diambil kembali apabila diperlukan. Akibatnya, formulir-formulir tersebut semakin hari semakin banyak jumlahnya sehingga memenuhi tempat pengarsipan. Dan apabila diminta pelaporan data keluar masuknya kendaraan, maka kita akan mencarinya dalam tumpukan berkas lampiran permohonan tersebut. Sangat jelas bahwa tindakan ini selain daripada adanya pemborosan juga akan memerlukan waktu yang cukup lama (Sholikhin \& Riasti, 2013).

Penelitian sebelumnya yang serupa yaitu Analisis dan Desain Sistem Informasi Monitoring Kendaraan di Lingkungan Perumahan (Wibisono, Nisafani, \& Fani, 2015). Metode yang yaitu menggunakan metode waterfall. Pada perancangan tersebut terdapat 2 aktor, yaitu petugas keamanan dan ketua RT, serta dapat dikembangkan rancangan antarmuka yang terdiri dari tiga menu utama untuk petugas keamanan dan dua menu utama untuk ketua RT. Penelitian lain yaitu Sistem Informasi Pengelolaan Kendaraan Bermotor Berbasis Web (Studi Kasus: Di PT.Telekomunikasi Indonesia, Tbk Area Cengkareng) (Yulianti, 2011). Desain sistem yang digunakan yaitu menggunakan Data Flow Diagram (DFD). Fitur yang dimiliki yaitu: 1) Daftar karyawan jika dibutuhkan untuk berpergian keluar kota, 2) Web pengelola peminjaman mobil, dan 3) Daftar karyawan, kendaraan bermotor (KBM), bbm dan servis dalam data laporan.

Mengingat sangat pentingnya pengelolaan data kendaraan pada PT PLN (Persero) Area Mojokerto, maka dalam hal ini dilakukan penelitian "Rancang Bangun Sistem Informasi Pengelolaan Kendaraan PT PLN (PERSERO) Area Mojokerto", Sistem Informasi Pengelolaan Kendaraan selanjutnya disebut SIPK, dengan penulisan penelitian ini diharapkan dapat bermanfaat bagi PT PLN Area Mojokerto.

\section{Metode Penelitian}

\subsection{Analisis Kebutuhan}

Berikut deskripsi dan analisis kebutuhan dari desain SIPK di PT PLN (Persero) Area Mojokerto berbasis $w e b$, antara lain:

1. Login

Proses ini dilakukan oleh admin, atasan, dan pegawai, dimana setiap elemen memiliki batasanbatasan dan fungsi tersendiri, untuk keamanan data yang terdapat formmasukan username, password dan status.Hak akses admin diantaranya yaitu mengatur dan menyeleksi permohonan yang masuk, menetapkan driver dan kendaraan yang akan dibawa untuk keperluan dinas luar, menambah dan mengurangi data karyawan, kendaraan data atasan, dan manajemen modul.Hak akses atasan diantaranya yaitu mengecek dan memberi izin kepada bawahannya. Hak akses loginpegawai diantaranya yaitu hanya menginputkan data identitas, tujuan, serta keperluan.

2. Manipulasi data

Proses ini berkaitan dengan pengisian data, misalnya proses peminjaman, proses pengesahan atasan bagian, proses pengesahan admin. Dilakukan oleh masing- masing bagian dan proses memperbarui, mengubah, menghapus, penetapan driver, dan kendaraan yang dilakukan oleh admin.

3. Transaksi data

Proses ini berkaitan dengan transaksi atau pengisian surat perintah jalan, jarak tempuh, dan pengisian BBM yang akan digunakan oleh poll kendaraan dinas.

4. Pencarian data

Proses ini berkaitan dengan pencarian data yang meliputi data karyawan, data pengemudi, data atasan, data kendaraan, data kota tujuan, data jumlah penumpang, dan data jarak tempuh.

5. Cetak laporan

Proses ini berkaitan dengan pencetakan data, surat pengantar, permohonan, serta laporan perjalanan meliputi pemakaian BBM yang terpakai dan kerusakan kendaraan.

6. Hak akses

Proses Ini berkaitan dengan pemberian hak akses pada setiap karyawan PT PLN (Persero) Area Mojokerto. 


\subsection{Perancangan Proses}

Untuk perancangan proses yang dibuat dalam aplikasi ini menggunakan bahasa pemrograman PHP. Proses pemodelan pada SIPK dengan menggunakan Flow Chart Diagram, ditampilkan pada Gambar 1.

\subsection{Pemodelan Sistem UML}

Pemodelan sistem terdiri dari use case dan aktor, diagram use case, diagram activity, diagram kelas, dan diagram squence. Pada diagram use case Gambar 2 menunjukkan bahwa admin dapat melakukan login sebagai admin, edit data, hapus data, view data, cetak data dan dapat memberikan hak akses kepada karyawan yang dikehendaki untuk memiliki hak tambah, hak edit, dan hak hapus.Karyawan yang belum terdaftar tidak memiliki hak akses, sedangkan karyawan yang sudah terdaftar maka memiliki hak login, input data, hapus data, view data dan cetak data layanan admin.Dimulai dengan mengakses, kemudian pegawai akan dihadapkan kepada halaman login, pada form login admin, atasan bagian/karyawan diminta memasukan username dan password yang telah ditetapkan oleh admin. Apabila username dan password yang dimasukan benar maka aktifitas selanjutnya ialah menampilkan halaman utama, akan tetapi jika username dan password salah, maka aktivitas selanjutnya ialah kembali ke form login. Adapun diagram use case dapat dilihat pada Gambar 2.

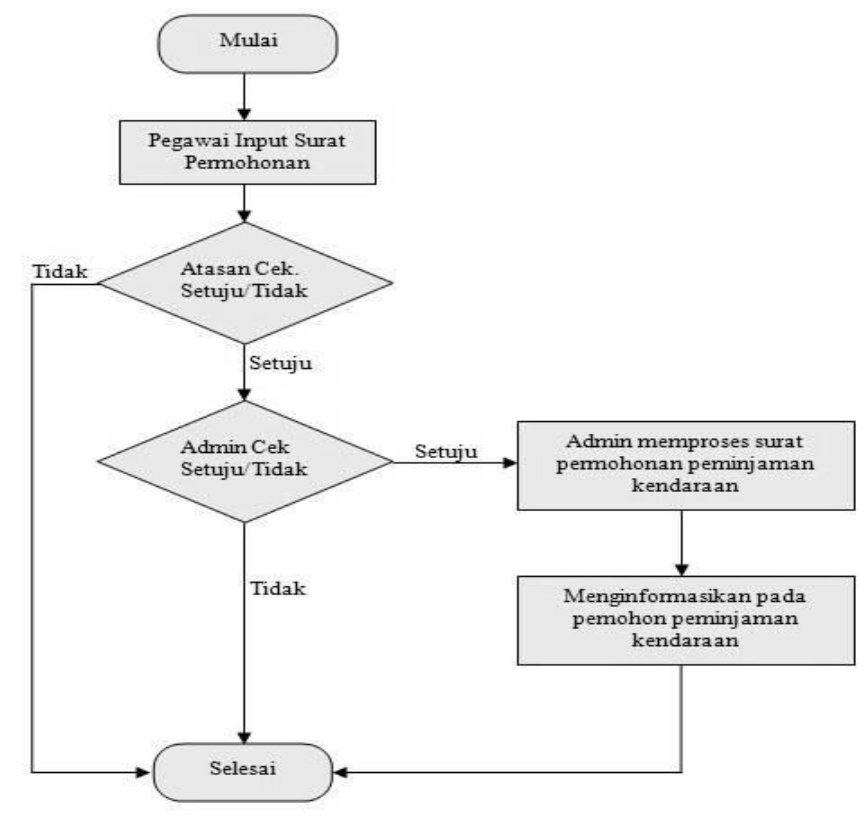

Gambar 1 Flowchart perancangan proses

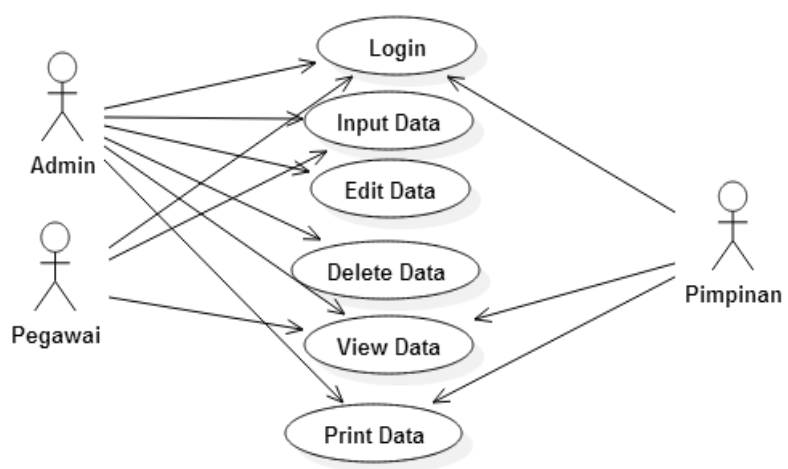

Gambar 2 Diagram use case sistem

Diagram aktifitasmenggambarkan berbagai aliran aktifitas dalam sistem yang sedang dirancang, secara umum sistem dibangun sesuai dengan level kebutuhan pada sistem, berikut ini adalah diagram activity pada SIPK, perhatikan Gambar 3. 


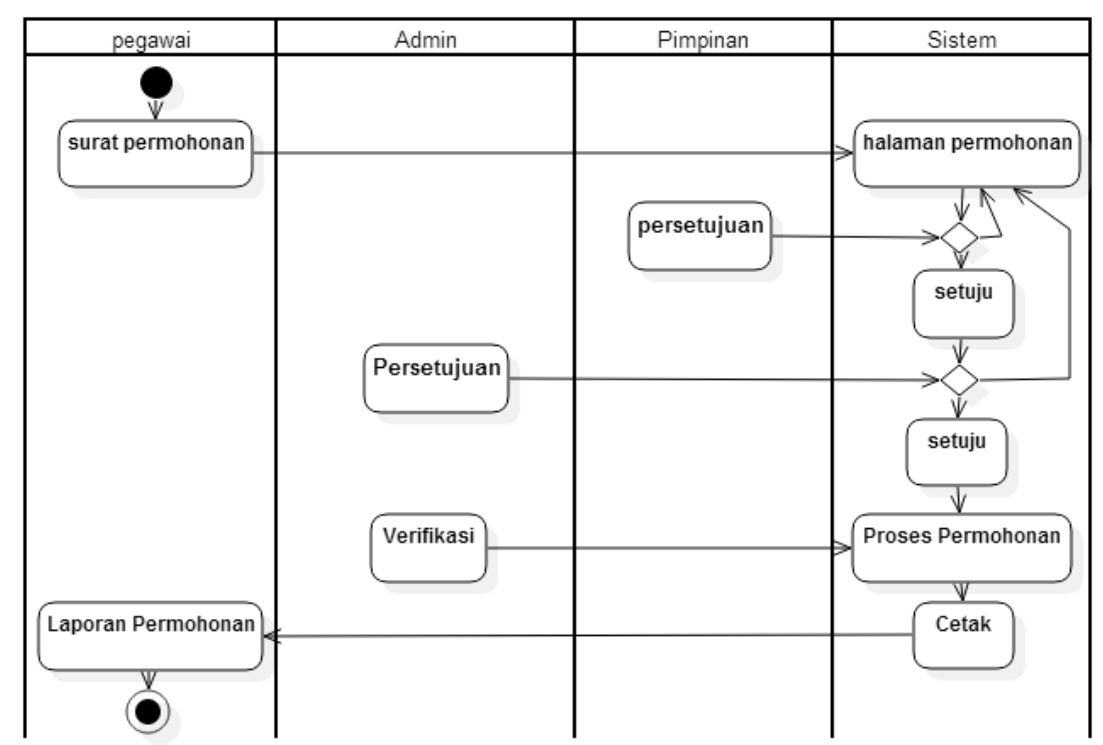

Gambar 3 Diagram activity

Kelas adalah sebuah spesifikasi yang jika diinstansiasi akan menghasilkan sebuah obyek dan merupakan inti dari pengembangan dan desain berorientasi obyek. Kelas menggambarkan keadaan (atribut/property) suatu sistem, sekaligus menawarkan layanan untuk memanipulasi keadaan tersebut (metoda/fungsi). Diagram kelas untuk use case SIPK ditampilkan pada Gambar 4.

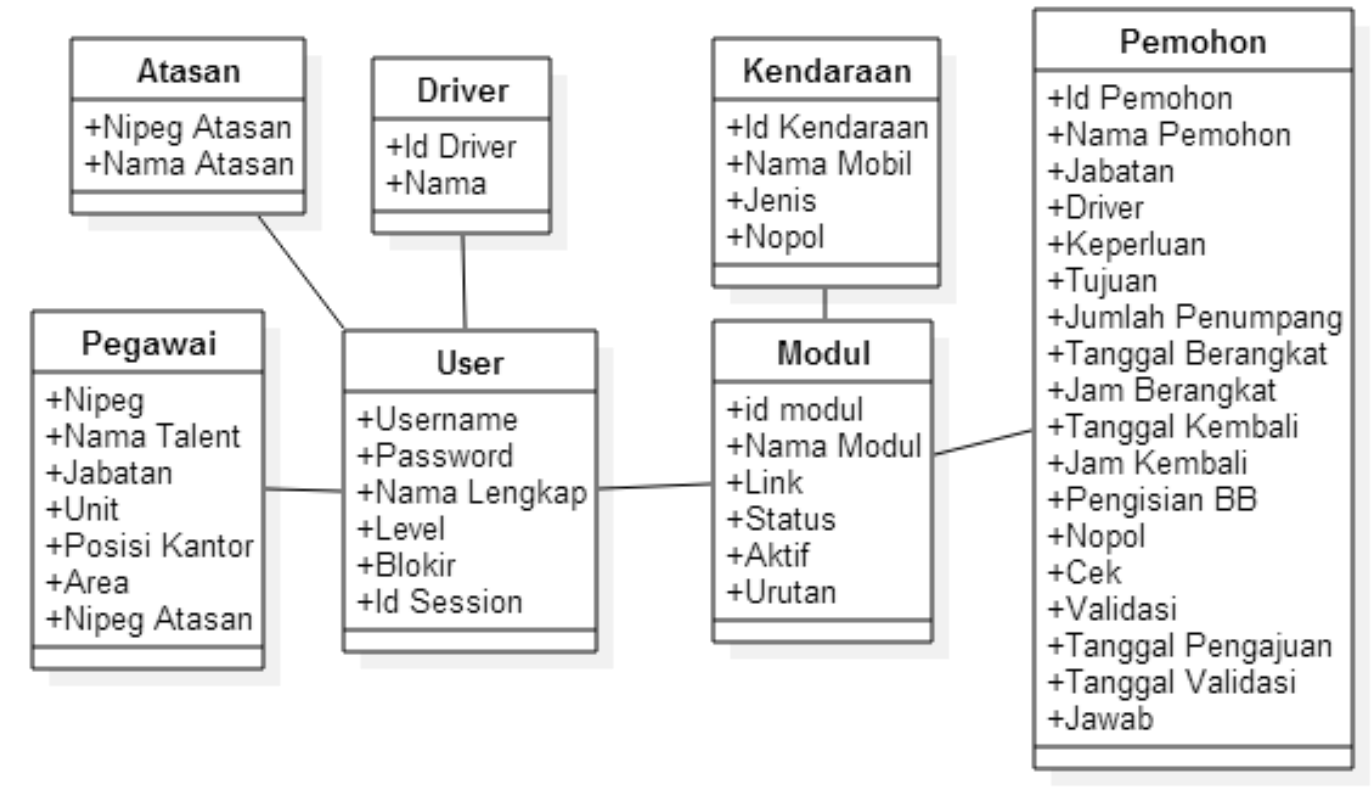

Gambar 4 Diagram kelas

Diagram sequence biasa digunakan untuk menggambarkan skenario atau rangkaian langkah yang dilakukan sebagai respons dari sebuah event untuk menghasilkan keluarantertentu. Diawali dari apa yang memicu aktifitas tersebut, proses dan perubahan apa saja yang terjadi secara internal dan keluaranapa yang dihasilkan. Contoh diagram sequence pada desain login sistem ini dapat dilihat pada Gambar 5.

\section{Hasil Penelitian dan Pembahasan}

Admin dalam hal ini sebagai pengguna yang memiliki hak akses sepenuhnya untuk bisa menambahkan pegawai, dan memasukkan data, update, delete,edit, cetak laporan, perincian data berbeda dengan pegawai yang hanya bisa memasukkan data dan mencetak laporan, begitu juga dengan atasan yang hanya menyetujui dan memblokir permohonan. 
Form login merupakan form yang memberikan hak akses kepada admin, pegawai dan atasan. Admin, pegawai Dan atasan yang bisa diakses adalah mereka yang sudah terdaftar dalam aplikasi pengeloaan kendaraan dinas, Gambar 6 adalah tampilannya dari form login.

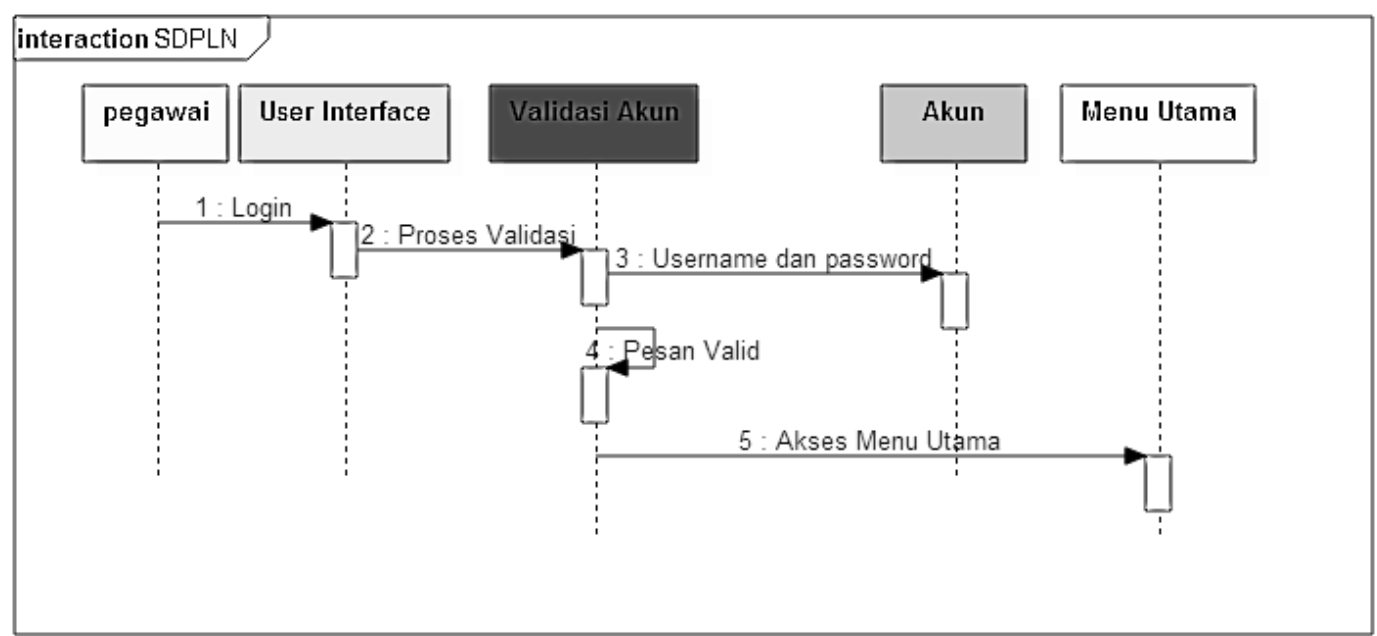

Gambar 5 Diagram sequence untuk use case login

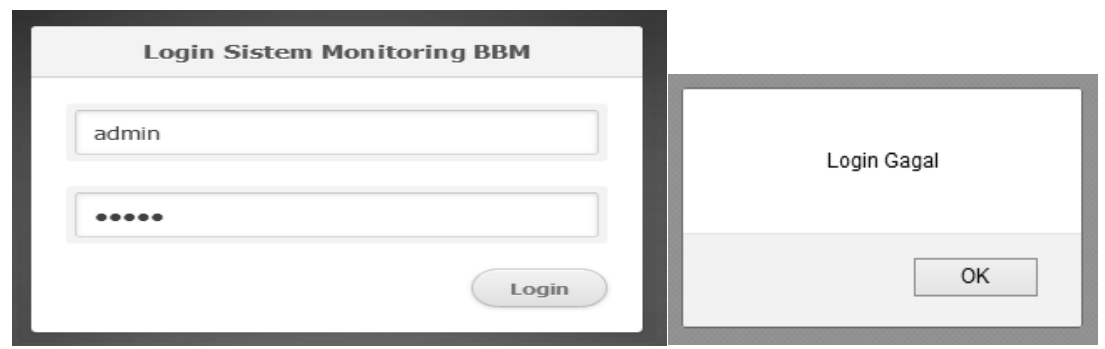

(a)

(b)

Gambar 6(a) Halaman depanlogin, dan (b) Login tidak berhasil

Halaman awal loginadmin apabila login sukses dilakukan, perhatikan Gambar 7 .

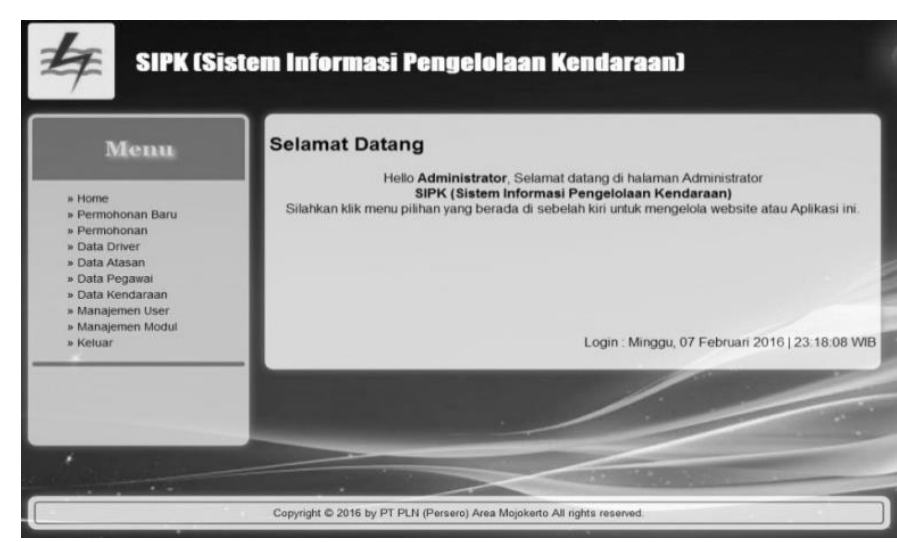

Gambar 7 Halaman awal Admin System

Pada halaman admin ini terdapat beberapa menu diantaranya yaitu, menu permohonan baru, menu permohonan, menu data driver, menu atasan, menu pegawai, data kendaraan, manajemen user, manajemen modul dan keluar. Semuanya memiliki fungsi dan kegunaan masing-masing yang dikuasai penuh oleh admin. Halaman utama pegawai setelah berhasil melakukan login diperlihatkan pada Gambar 8.

Pada halaman pegawai terdapat beberapa menu diantaranya yaitu: Menu home, menu arsip, menu permohonan, dan keluar.Halaman utama atasan setelah berhasil melakukan login, diperlihatkan pada Gambar 9.Pada tampilan menu atasan hanya terdapat tiga (3) menu diantaranya yaitu: menu home, menu 
permohonan, dan menu keluar. Pada menu permohonan baru (Gambar 10) didalam menu admin terdapat tabel aksi yang berisi validasi yang fungsinya yaitu untuk mengisikan driver dan kendaraan dinas yang akan dipakai oleh pengaju permohonan, perhatikan Gambar 11.Pada menu ini, driver dan kendaraan diisi oleh admin dan setelah diisi dan disimpan, maka data akan otomatis pindah ke menu permohonan, Gambar 12 adalah tampilan dari menu permohonan.

Pada menu ini terdapat beberapa kolom diantaranya yaitu kolom aksi yang berfungsi untuk mencetak, memasukkan, menghapus,dan apabila admin menghendaki untuk mencetak permohonan maka akan tampil pada Gambar 13.

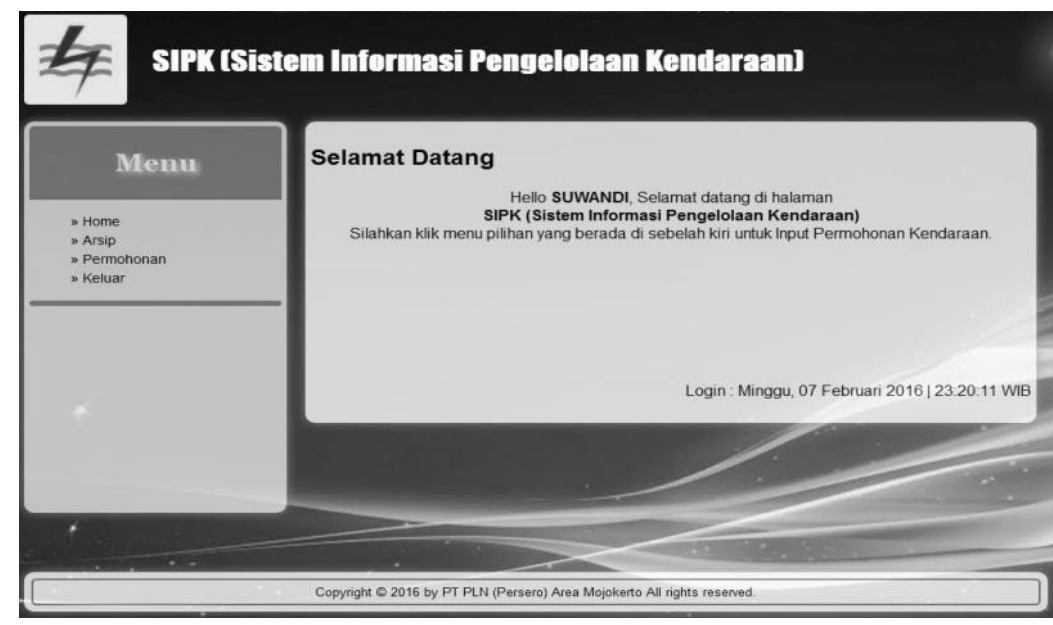

Gambar 8 Halaman awal pegawai

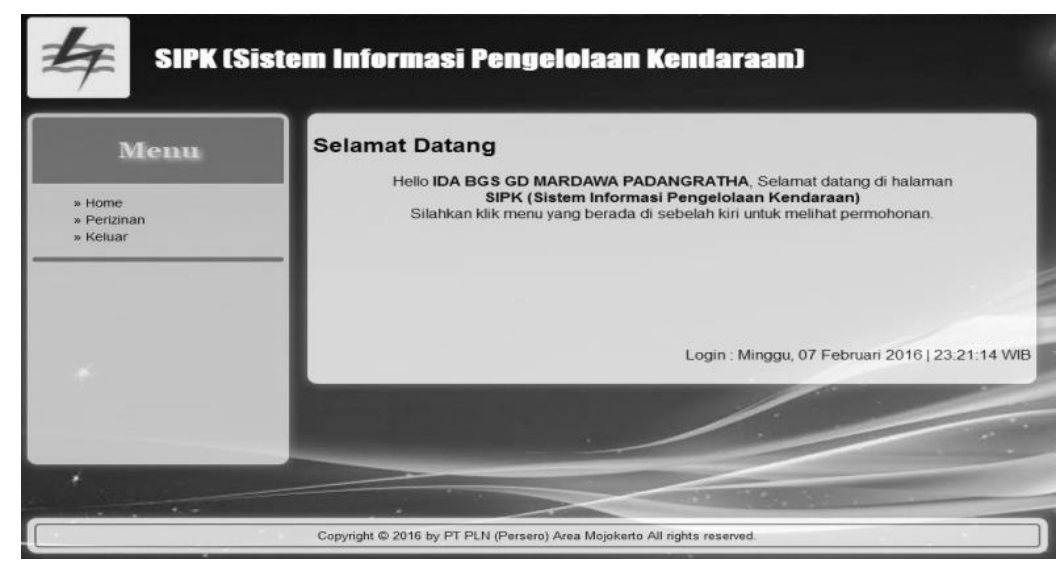

Gambar 9 Halaman utama atasan

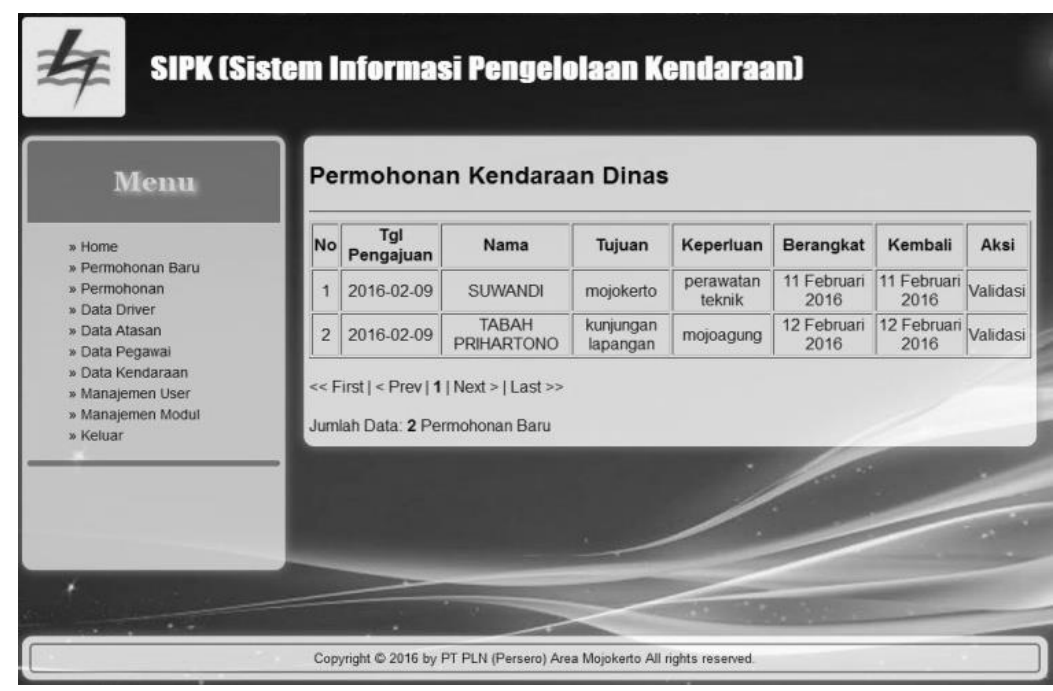

Gambar 10 Menu permohonan baru admin

Register: Jurnal Ilmiah Teknologi Sistem Informasi, Januari 2015, Volume 1, Nomor 1 | 29 


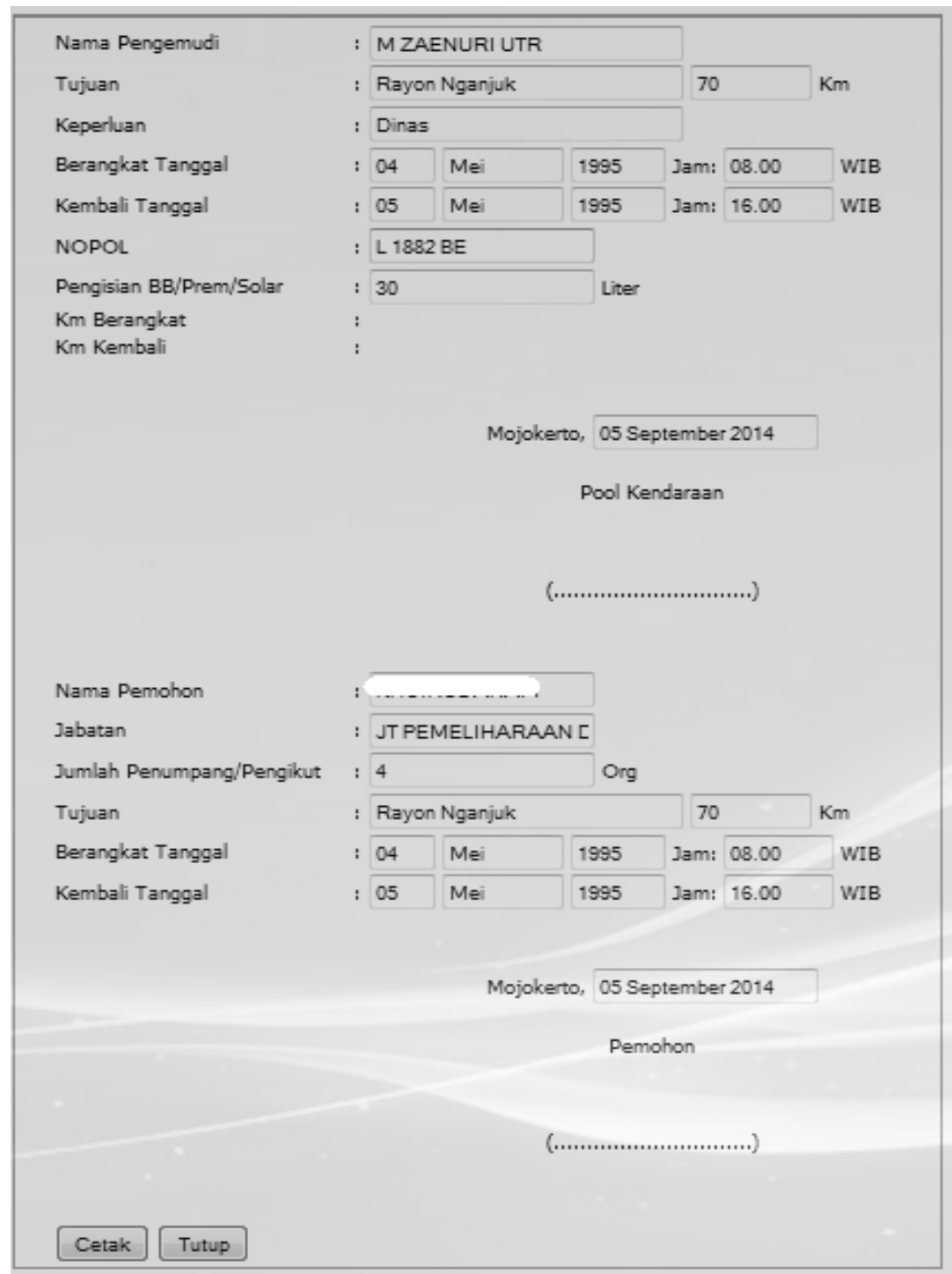

Gambar 11 Form pengisian driver

\section{SIPK ISistem Informasi Pengelolaan Kendaraan]}

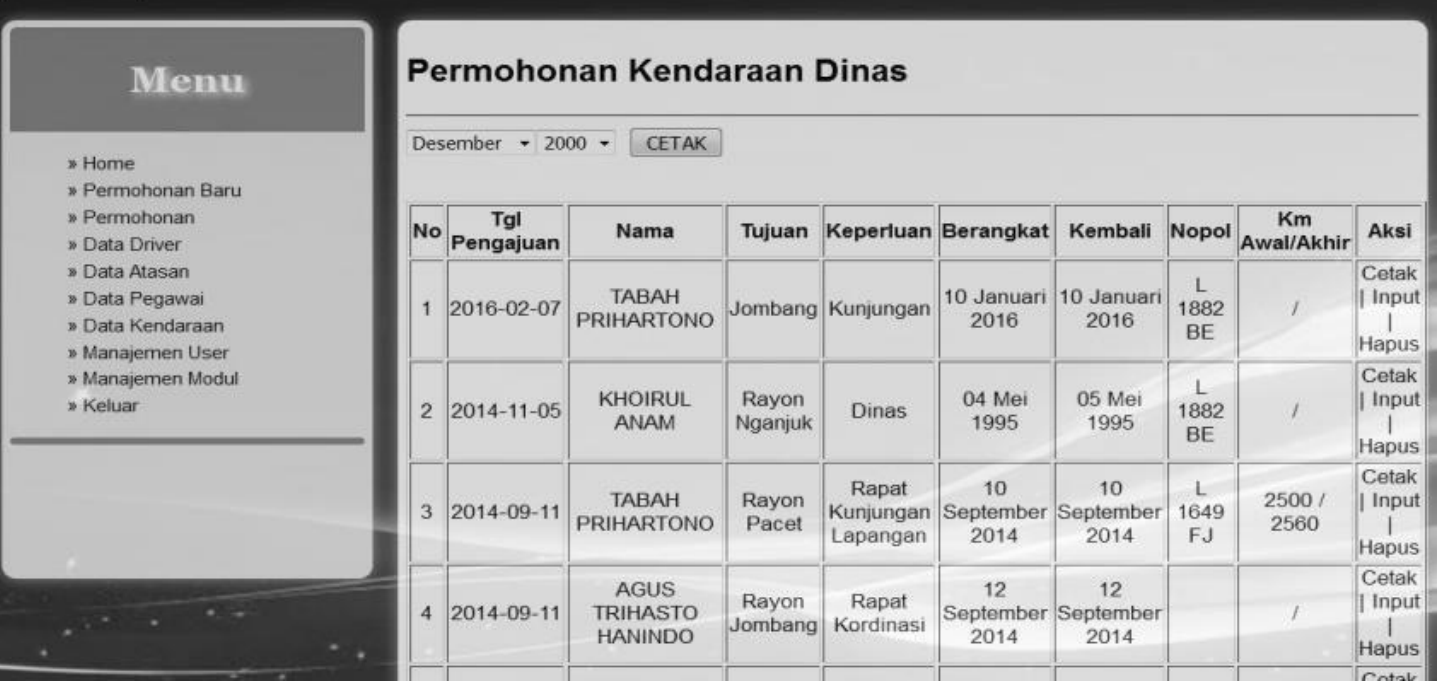

Gambar 12 Menu permohonan admin 


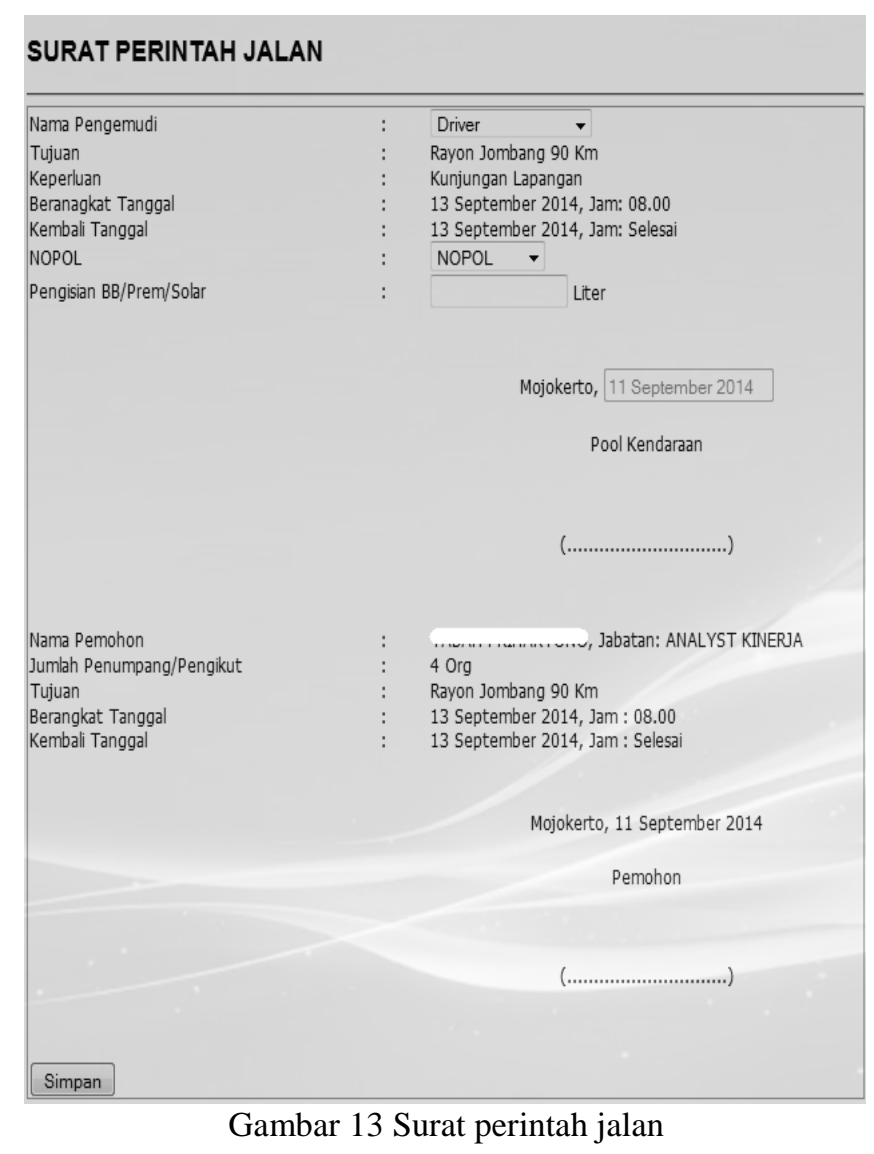

Surat perintah jalan ini dibawa oleh driver yang diberikan oleh admin hasil dari menu cetak pada kolom aksi pada halaman admin.Menu masukan pada kolom aksi, menu masikan ini berfungsi untuk mengisi $\mathrm{km}$ berangkat dan $\mathrm{km}$ kembali yang fungsinya untuk mengetahui jarak tempuh kendaraan dinas selama dibawa tugas, perhatikan Gambar 14.

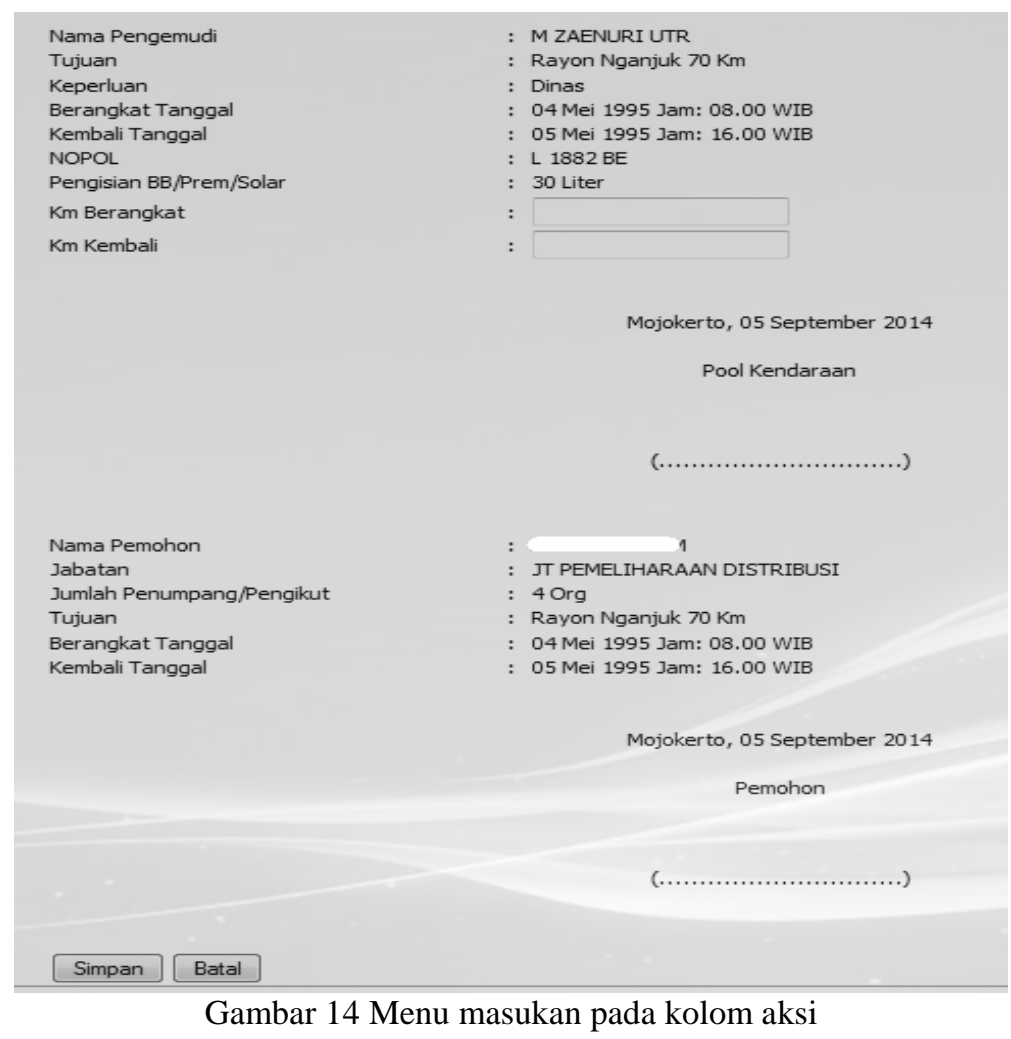

Register: Jurnal Ilmiah Teknologi Sistem Informasi, Januari 2015, Volume 1, Nomor 1 | 31 


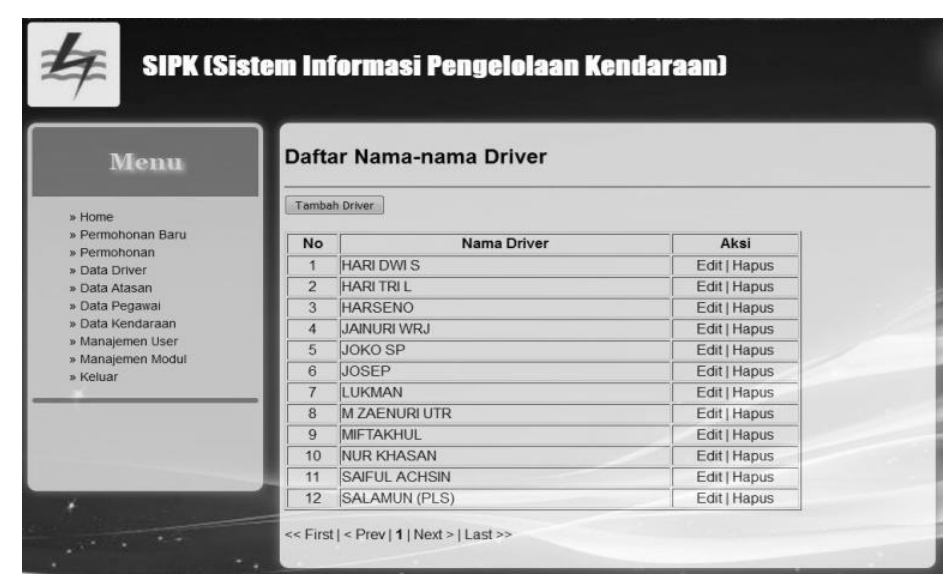

Gambar 15 Menu driver

Menu ini digunakan admin untuk mengisikan jarak tempuh kendaraan selama dipakai untuk tugas. Selanjutnya yaitu menu hapus pada kolom aksi berfungsi untuk menghapus data. Pada menu pemohon juga terdapat menu pencarian, berfungsi untuk mencari data yang diinginkan berdasarkan bulan dan tahun. Selanjutnya menu driver pada halaman admin.

Menu driver dalam halaman admin, didalam menu ini terdapat beberapa kolom diantaranya yaitu kolom nama driver dan kolom aksi,kolom aksi memiliki dua (2) menu yaitu menu edit dan menu hapus, perhatikan Gambar 15. Menu edit berfungsi untuk mengubah nama driver, sedangkan kolom hapus berfungsi untuk menghapus driver. Selain itu terdapat juga menu tambah driver, berfungsi untuk menambahkan driver baru, perhatikan Gambar 16.

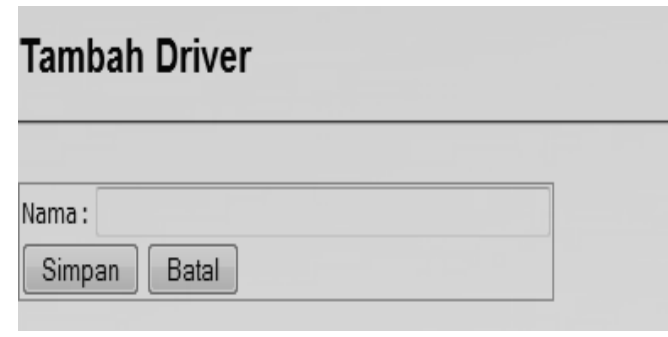

Gambar 16 Tambah driver

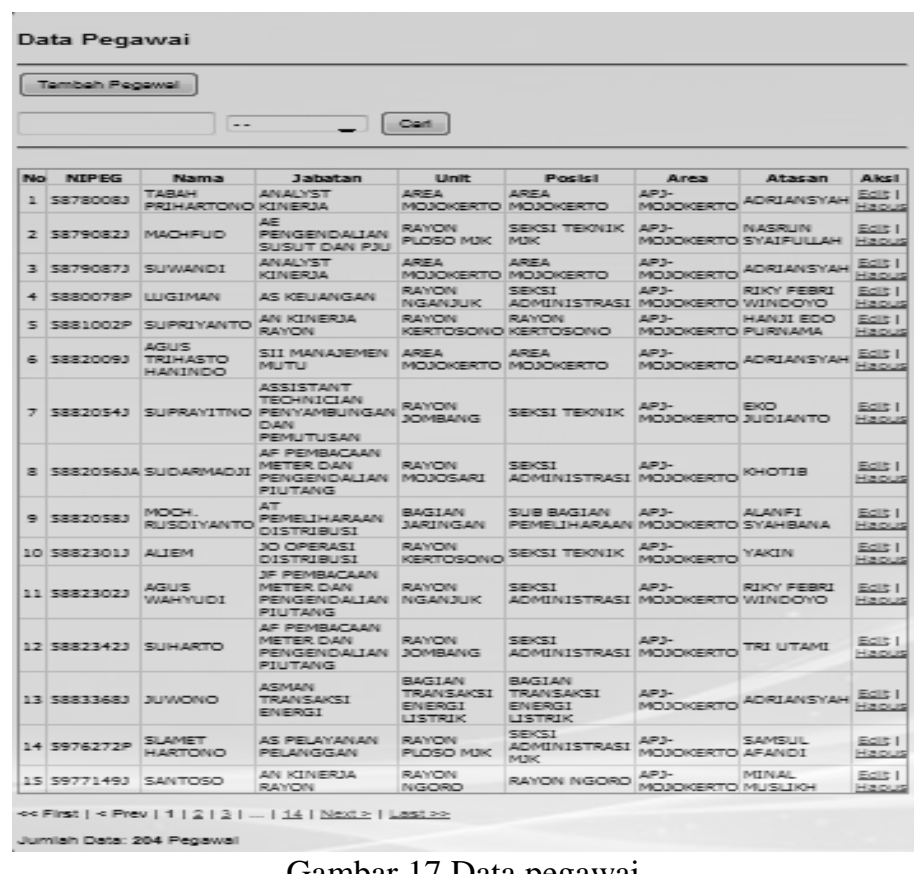

Gambar 17 Data pegawai 
Berikutnya yaitu menu data atasan pada halaman admin, didalam menu ini berisikan semua atasan PT PLN (Persero) Area Mojokerto, Gambar 17 adalah tampilan data menu atasan.

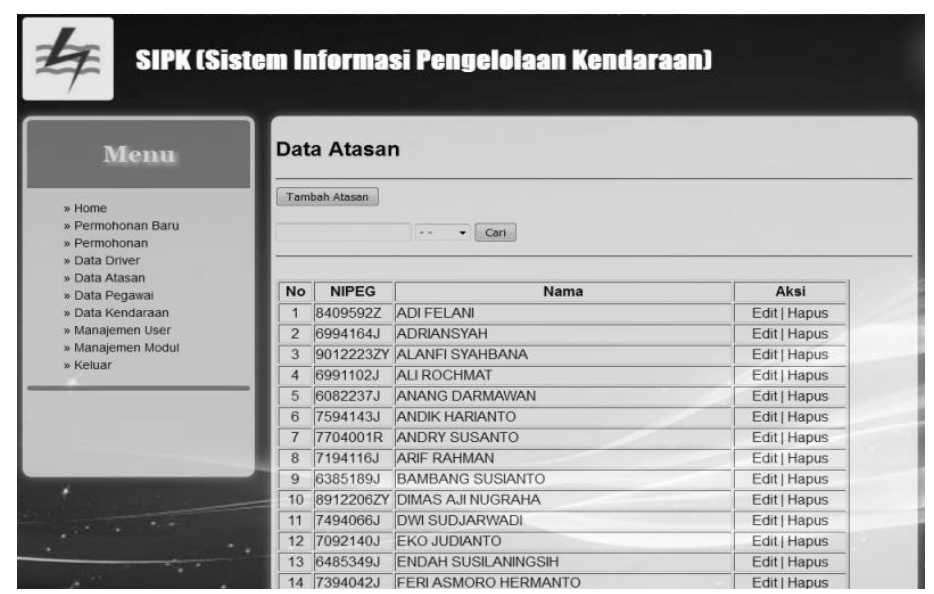

\section{Gambar 18 Data atasan}

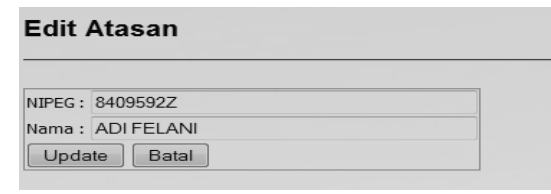

Gambar 19 Data edit atasan

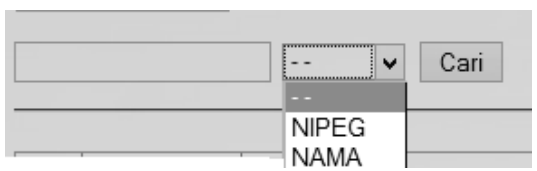

Gambar 20 Pencarian atasan

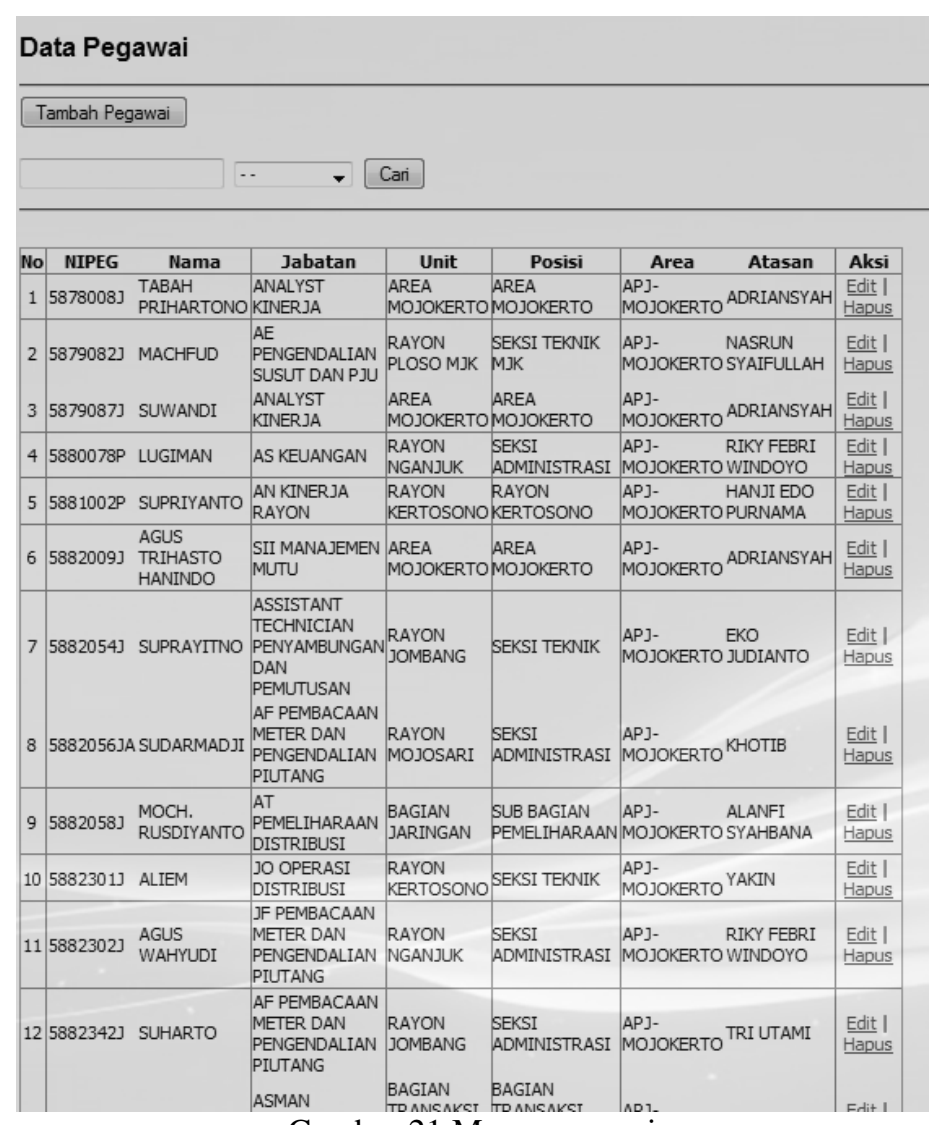

Gambar 21 Menu pegawai 
Pada tampilan ini terdapat beberapa kolom diantaranya yaitu kolom aksi, pada kolom aksi ini terdapat menu edit dan hapus yang memiliki fungsi masing- masing, dan pada menu ini juga dilengkapi dengan kolom pencarian berdasarkan nipeg, nama, jabatan, posisi, atasan.Menu atasan dalam kolom admin memiliki 3 (tiga) kolom yaitu kolom nipeg, nama atasan, dan kolom aksi, serta dilengkapi dengan tombol pencarian. Kolom aksi terdapat 2 (dua) menu yaitu edit dan hapus. Menu edit berfungsi untuk edit data atasan (Gambar 19).Sedangkan tombol pencarian berfungsi untuk mencari data yang di inginkan berdasarkan nipeg dan nama atasan (Gambar 20).

Selain itu pada halaman admin juga terdapat menu data pegawai, didalam menu ini terdapat semua data karyawan PT PLN (Persero) Area Mojokerto. Menu ini juga terdapat beberapa kolom diantaranya, yaitu kolom aksi yang memiliki dua menu yaitu menu edit, hapus dan memiliki fungsi masing-masing, selain itu menu ini juga memiliki table hasil pencarian dan tambah pegawai (Gambar 21).

Masih dalam halaman admin, ketika dihadapkan kepada halaman admin tentu akan menjumpai menu driver, didalam menu driver akan menjumpai data-data kendaran dinas yang dimiliki oleh PT PLN (Persero) Area Mojokerto, pada halaman ini juga dilengkapi dengan beberapa kolom diantaranya yaitu kolom aksi, disana dapat dijumpai dua menu didalamnya, yaitu menu edit dan menu hapus juga dalam halaman ini dijumpai pula tombol tambah kendaraan (Gambar 22).

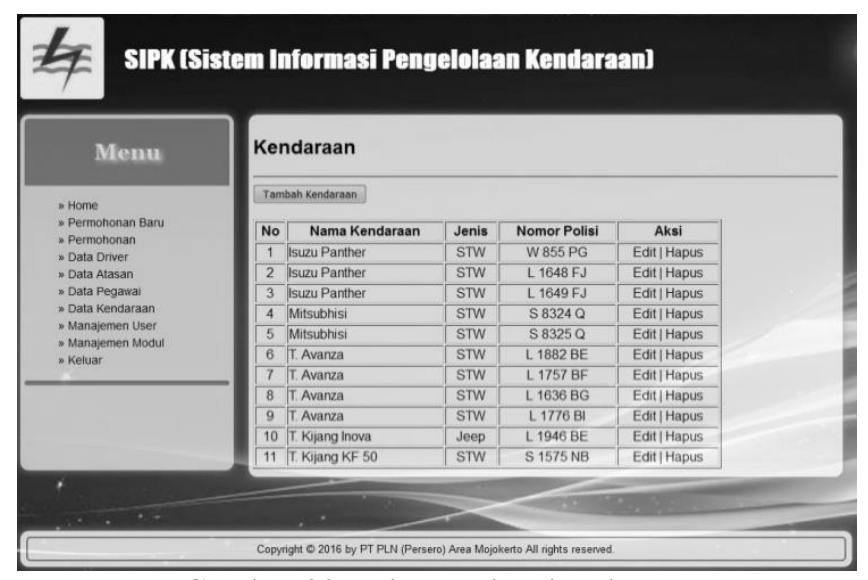

Gambar 22 Halaman data kendaraan

Selanjutnya masih dalam halaman admin, yaitu pada menu manajemen user, pada manajemen user ini akan dihadapkan pada data-data pegawai, juga dilengkapi dengan beberapa kolom diantaranya yaitu kolom blokir dan kolom aksi, kolom blokir berfungsi untuk melihat data yang aktif jika datanya $\mathrm{N}$, maka data aktif, sedangkan Y, maka data terbelokir. Jika data terbelokir, maka data tidak akan terlihat dalam menu data pegawai, untuk mengaktifkannya cukup update pada kolom aksi dengan menekan menu edit(Gambar 23).Kemudian jika klik menu edit pada kolom aksi, maka kita akan dihadapkan pada menu sebagai berikut (Gambar 24).

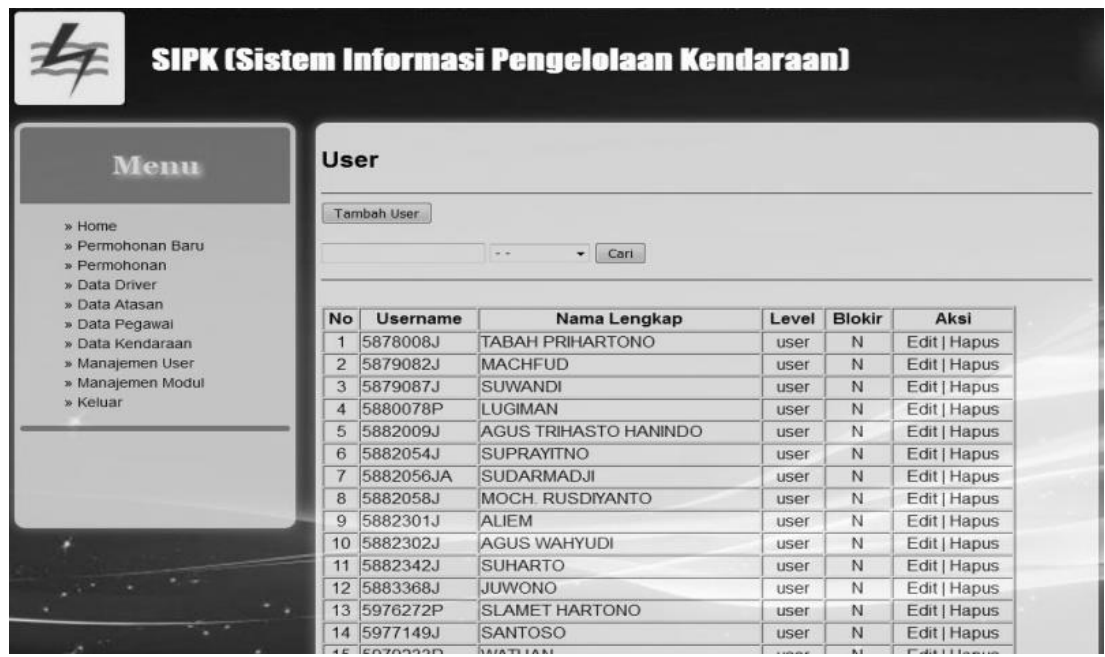

Gambar 23 Manajer user

34 | Register: Jurnal Ilmiah Teknologi Sistem Informasi, Januari 2015, Volume 1, Nomor 1 


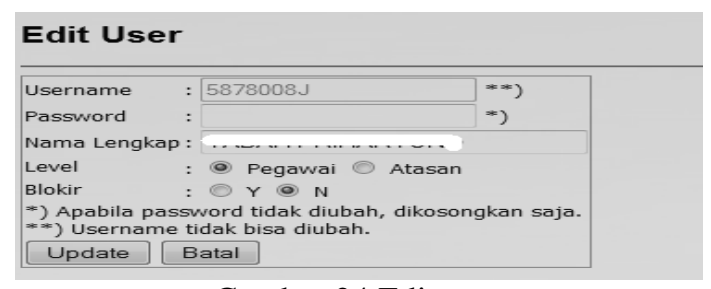

Gambar 24 Edit user

Pada menu pada Gambar 20 dapat dilihat dua radio buton yaitu pegawai dan atasan, jika diklik pada button pegawai, maka data username menjadi data pegawai, dan langsung masuk pada menu pegawai pada halaman admin begitu juga sebaliknya, sedangkan 2 radio buton dibawahnya, yaitu $\mathrm{Y}$ dan $\mathrm{N}$ berfungsi untuk mengaktifkan atau menblokir data, apabila data $\mathrm{N}$ maka data akan tampil pada data pegawai atau data atasan pada menu di halaman admin, jika Y maka data terblokir dan tidak akan tampil pada menu pegawai ataupun menu atasan.Kemudian menu selanjutnya adalah menu manajemen modul yang masih dalam halaman admin, disana dapat dijumpai Gambar 25.

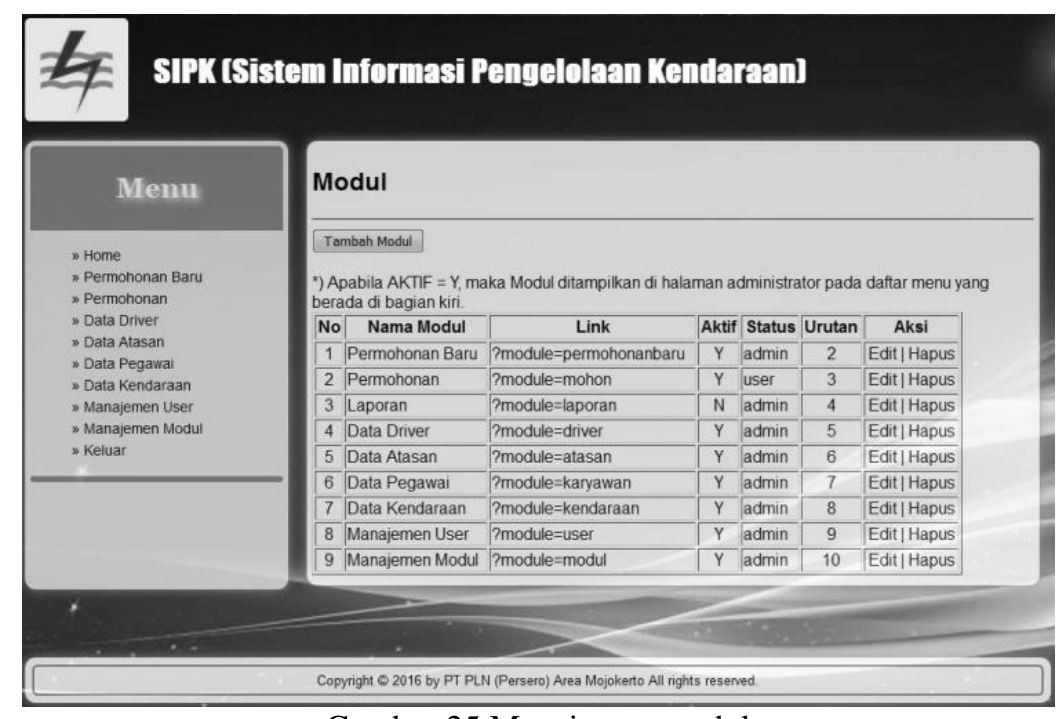

Gambar 25 Manajemen modul

Pada menu Gambar 25 berfungsi untuk mengatur menu-menu yang dapat dilihat pada halaman admin, pada halaman ini pula dapat menambahkan menu, ataupun menghapus menu yang tidak terpakai, juga bisa mengubah menu pada kolom aksi yaitu pada menu edit, Gambar 26.

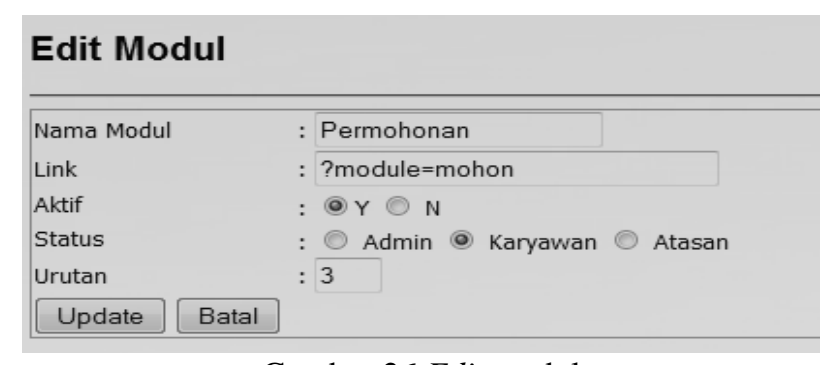

Gambar 26 Edit modul

Pada tampilan Gambar 26 merupakan tampilan dari menu edit, pada kolom aksi, disini akan dihadapkan pada beberapa pilihan diantaranya, yaitu menu aktif disana terdapat $\mathrm{Y}$ dan $\mathrm{N}$ berfungsi untuk mengaktifkan atau membelokir data, jika $\mathrm{N}$ maka data akan tampil sebagai menu pada halaman admin, jika Y maka data tidak akan muncul, begitu juga dengan menu status disana terdapat button admin, karyawan dan atasan berfungsi untuk menempatkan menu di mana data ini akan diletakkan. Selanjutnya yang terakhir adalah menu keluar, dimana menu ini hanya berfungsi untuk memindahkan atau menutup halaman admin. 


\section{Kesimpulan}

Berdasarkan uraian sebelumnya, maka dapat ditarik beberapa kesimpulan dari penelitian ini adalah SIPK di PT PLN (Persero) Area Mojokerto ini sudah bisa mencatat laporan penggunaan kendaraan dinas, mengetahui keluar masuknya kendaraan dinas, mampu mempercepat proses cetak laporan kendaraaan dinas dan menghemat waktu dalam pengerjaan sehingga membuat kinerja menjadi efisien.

SIPK di PT PLN (Persero) Area Mojokerto ini jauh dari kata sempurna seperti yang diharapkan, oleh karena itu pengembang selanjutnya bisa dilakukan. Diperlukan sumber daya manusia untuk maintenance progam SIPK yang telah dibuat, diperlukan juga backup data jika sewaktu-waktu terjadi kerusakan pada perancangan SIPK ini. Pengembangan rancang bangun aplikasi hendaknya dapat diterapkan di PT PLN (Persero) Area Mojokerto.

\section{Referensi}

Lubis, R. S. (2013). Sistem Informasi Pemasaran Pada Showroom Mutiara Motor Berbasis Web. Medan: Universitas Sumatra Utara.

Sholikhin, A., \& Riasti, B. K. (2013). Pembuatan Sistem Informasi Inventarisasi Sekolah Pada Dinas Pendidikan Kabupaten Rembang Berbasis Web. Indonesian Jurnal on Networking and Security (IJNS), 2(2), 50-57.

Subchan, \& Ardi, B. K. (2014). Peranan Strategi Sistem Informasi Manajemen Untuk Mencapai Tujuan. Jurnal Ekonomi Manajemen dan Akuntansi, 21(36), 1-14.

Wibisono, A., Nisafani, A. S., \& Fani, S. V. (2015). Analisis Dan Desain Sistem Informasi Monitoring Kendaraan Dilingkungan Perumahan. Seminar Nasional Sistem Informasi Indonesia (halaman. 157-162). Surabaya: Sistem Informasi Fakultas Teknologi Informasi Institut Teknologi Sepuluh Nopember.

Yulianti, S. (2011). Sistem Informasi Pengelolaan Kendaraan Bermotor Berbasis Web (Studi Kasus: Di PT.Telekomunikasi Indonesia,Tbk Area Cengkareng). Bandung: Politeknik Telkom. 